\title{
Pelatihan Origami Bagi Anak Usia Dini di PAUD Jannatul Na'iem Sungai Buluh
}

\section{Lady Diana Yusri, Adrianis, Aulia Rahman, Darni Enzimar Putri, Dini Maulia, Idrus, Imelda Indah Lestari, Rachmidian Rahayu, Radhia Elita, Rahtu Nila Sepni, Rima Devi, Rina Yuniastuti}

Fakultas Ilmu Budaya, Universitas Andalas, Kampus Limau Manis, Padang, 25163. Indonesia

E-mail: ladydianayusri@hum.unand.ac.id

Keywords:

children,

creativity, origami

Kata Kunci: anak usia dini, kreativitas, origami

\begin{abstract}
Origami is one of the arts in folding paper from Japan. Through this origami workshop, not only adults, even the children, could increase their imagination and creativity in the early years. Based on this reason, Japanese Department of Universitas Andalas carried out the Origami workshop to the children in the PAUD Jannatul Nai'em Sungai Buluh. This workshop is a part of community service as the lecturer of the University. The workshop activity provided three sessions. The first session was to give an introduction about origami for understanding, history, types, and benefits of origami. The second session was training on making origami in various forms. Then the last session was evaluation, which aims to confirm whether the children could absorb the material well and whether the children could work on the process of making origami on their own. This activity was very beneficial for children in improving their motoric skills. Origami is an alternative skill game where the skill games begin to abandon due to the presence of a smartphone and other digital gadgets.
\end{abstract}
ABSTRAK
Keterampilan origami merupakan salah satu kesenian berupa keterampilan melipat kertas dari Jepang. Melalui pelatihan membuat origami ini diharapkan anak usia dini dapat meningkatkan imajinasi dan kreativitasnya sebagai pelajar. Pengenalan origami dilakukan sebagai kegiatan pengabdian kepada masyarakat oleh Jurusan Sastra Jepang di PAUD Jannatul Nai'em Sungai Buluh. Kegiatan pengabdian yang diberikan berupa pelatihan yang terdiri dari 3 sesi. Sesi pertama yaitu memberikan pengetahuan tentang origami meliputi pengertian, sejarah, jenis-jenis, dan manfaat origami bagi pelajar. Sesi kedua merupakan sesi pelatihan membuat origami dengan berbagai bentuk. Selanjutnya sesi terakhir yaitu sesi evaluasi, yang bertujuan untuk memastikan apakah para pelajar atau peserta pelatihan dapat menyerap materi dengan baik serta apakah pelajar tersebut dapat mengerjakan proses pembuatan origami sendiri tanpa pendampingan atau tidak. Kegiatan ini sangat memberikan manfaat bagi anak usia dini dalam hal meningkatkan kemampuan motorik. Origami juga dapat dijadikan alternatif permainan, dimana permainan keterampilan mulai ditinggalkan akibat keberadaan ponsel dan gawai digital lainnya. 


\section{PENDAHULUAN}

Pengabdian pada masyarakat merupakan salah satu dari Tri Dharma Perguruan Tinggi yang bertujuan untuk memberikan manfaat kongkrit profesi dosen kepada masyarakat. Program pengabdian masyarakat berbasis program studi di tahun 2019 yang dilakukan oleh Jurusan Sastra Jepang kali ini bertujuan untuk meningkatkan kreativitas anak-anak usia dini melalui keterampilan origami. Kegiatan ini bertujuan untuk menambah atau meningkatkan kreativitas anak-anak melalui kesenian dan keterampilan dari Jepang yaitu origami.

Pengguna layanan di era digital seringkali abai dengan lingkungan sekitar karena fokus dengan alat digital yang digenggamnya. Hal ini juga berimbas pada anak-anak yang sering terabaikan oleh orang tua mereka. Anak-anak yang seharusnya mendapatkan perhatian langsung dari orang tua, menjadi tidak begitu atau kurang mendapatkan perhatian. Apalagi orang tua yang bekerja di luar rumah, merasa sulit menyisihkan waktu untuk memberikan perhatian kepada anak karena tantangan era digitalisasi sekarang ini. Disebabkan kurangnya perhatian tersebut, maka anak-anak dapat memiliki kecenderungan untuk mencari perhatian di luar rumah. Hal tersebut dapat mereka lakukan melalui jalur positif dan dapat pula melalui jalur yang negatif.

Jalur positif misalnya anak-anak mengikuti kegiatan luar rumah atau kegiatan luar sekolah yang dapat menampung kreativitas anak atau kegiatan yang dapat menyalurkan energi motorik mereka. Hal ini tentunya akan menimbulkan permasalahan serius pada perkembangan karakter anak-anak apabila kreativitas dan energi mereka disalurkan pada lingkungan yang salah. Seperti bergaul dengan kelompok anak-anak tidak berpendidikan yang kemudian akan mempengaruhi karakter buruk kepada anak di masa akan datang.

Penyebaran penggunaan alat digital untuk anak-anak menghasilkan dampak yang tidak baik bagi perkembangan sosial di usia dini. Anak-anak yang telah terpapar alat digital seperti ponsel atau gawai lainnya menyebabkan rendahnya kreatifitas dalam hal motorik. Oleh karenanya, kegiatan seni melipat kertas (origami) dicoba untuk diperkenalkan bagi anak-anak usia dini. Hal ini diharapkan agar origami dapat menjadi alternatif permainan yang dapat dipilih anak-anak untuk meningkatkan gerak motorik serta daya kreatifitas sembari bermain. Taman Pendidikan Anak Usia Dini (PAUD) Jannatul Na'iem Sungai Buluh dipilih sebagai tempat pelaksanaan pengabdian.

PAUD Jannatul Na'iem terletak di Kabupaten Padang Pariaman, Provinsi Sumatera Barat. Pelaksanaan pengabdian kepada masyarakat di lokasi ini sudah banyak dilakukan, diantaranya Yanti, dkk (2016) dengan judul Pemanfaatan Sludge Hasil Ikutan Biogas dari Kotoran Sapi Untuk Pembuatan Kompos Pada Kelompak Tani Indah Sakato Kenagarian Kasang, Kecamatan Batang Anai Kabupaten Padang Pariaman. Kegiatan ini dilakukan untuk mengedukasi kelompok tani di Padang Pariaman tentang pembuatan kompos secara mandiri. Kegiatan Pengabdian dengan sasaran kelompok tani di Pariaman juga pernah dilakukan oleh Agustina, dkk pada tahun 2016 juga melaksanakan pengabdian yang berjudul "Pembekalan Program Anti Korupsi kepada Penerima Dana Gempa di Kenagarian Pakandangan, Kabupaten Padang Parimaan". Sasaran kegiatan ini adalah masyarakat Kabupaten Padang Pariaman yang menerima dana bantuan dari pemerintah.

Diantara kegiatan pengabdian yang telah dilakukan di Kabupaten Padang Pariaman, keseluruhannya dilaksanakan dengan sasaran masyarakat, dalam artian orang dewasa. Sedikit sekali kegiatan khusus yang diadakan untuk pelatihan bagi anak-anak. Oleh karenanya, PAUD Jannatul Na'iem dipilih sebagai tempat kegiatan pengabdian dilaksanakan untuk pengembangan wilayah pendidikan di Kabupaten Padang Pariaman.

\section{METODE}

Sasaran kegiatan pelatihan membuat origami kali ini adalah anak-anak usia dini yang rentan terhadap pengaruh negatif era digital. Anak-anak usia dini tersebut adalah siswa PAUD. Pada 
kegiatan kali ini, pendidikan tingkat usia dini yang dipilih adalah PAUD Jannatul Na'iem di Sungai Buluh. PAUD ini dipilih karena sebelumnya Dosen Jurusan Sastra Jepang telah beberapa kali melakukan pengabdian masyarakat di Sungai Buluh. Maka pengabdian kali ini merupakan lanjutan pengabdian sebelumnya. Pelatihan pembuatan origami ini diharapkan dapat sebagai alternatif permainan bagi anak usia dini dan diharapkan dapat meningkatkan kreatifitas anak. Selain itu, dikarenakan pelatihan origami kali ini bertemakan tanaman, maka diharapkan juga dapat sebagai simulasi permainan untuk untuk mencintai tanaman dan lingkungan.

Metode yang digunakan dalam kegiatan ini adalah model penyuluhan dan pelatihan yang dilaksanakan dengan cara memberikan penyuluhan berupa pengertian origami, sejarah origami dan pengetahuan lainnya berkaitan dengan origami. Selanjutnya adalah memberikan model pelatihan dalam bentuk workshop kepada anak-anak PAUD. Pelatihan yang diberikan adalah cara membuat beberapa bentuk origami, dengan tema tanaman.

Evaluasi yang dilakukan terhadap peserta pelatihan adalah dengan memberikan pertanyaan dalam bentuk game, yang berfungsi untuk mencek kembali seberapa jauh pemahaman mereka terhadap penyuluhan yang telah diberikan. Selain itu, diberikan juga waktu untuk mereka membuat bentuk origami sendiri tanpa pendampingan. Hal ini dilakukan untuk mengevaluasi apakah para peserta telah menguasai dengan baik pelatihan yang telah diberikan.

Media utama untuk pembuatan origami ini adalah berupa lembaran kertas yang biasanya warna dan corak menarik. Bahan dasar pembuatan origami sangat mudah diperoleh. Hal ini menjadikan origami sebagai seni yang dapat diakses oleh semua kalangan. Beberapa karakteristik kertas yang digunakan untuk origami, antara lain; tipis, kuat, tidak mudah robek, dan tidak sulit untuk dilipat. Kertas origami sebaiknya tidak terlalu tipis dan tidak terlalu lentur seperti kertas tissue, juga tidak terlalu tebal seperti kertas karton. Untuk mengajarkan pembuatan origami kepada anak-anak dalam rentang usia dini, metode digunakan adalah dengan memberikan beberapa pengarahan kemudian mencontohkan atau memeragakan langsung cara membuat origami. Anak-anak yang hadir dan mengikuti kegiatan ini juga diarahkan untuk langsung mengikuti apa yang penulis contohkan di depan.

\section{HASIL DAN PEMBAHASAN}

Origami merupakan seni tradisional melipat kertas yang berasal dari Jepang. Saat ini seni tradisional ini telah berkembang menjadi seni modern yang terlihat dari bentuk-bentuk yang dihasilkan menjadi tambah rumit dan menghasilkan produk 3 (tiga) dimensi yang lebih modern seperti bentuk robot, mesin dan lainnya. Pada awalnya origami diperkenalkan oleh Tsai Lun, kebangsaan Tiongkok pada tahun 105 yang muncul tidak lama setelah ditemukannya kertas. Pada abad ke 6 atau sekitar tahun 610 seorang biksu dari Korea memperkenalkan cara membuat kertas dan tinta ke Jepang. Semenjak saat itu, penggunaan kertas dan seni melipat kertas mulai berkembang mulai hanya dari kalangan istana dan hanya pada saat perayaan tertentu saja hingga menyebar ke masyarakat biasa. Tidak saja penyebaran di tengah masyarakat Jepang saja, tapi juga berkembang pula di luar negri seperti Eropa.

Kegiatan origami memiliki beberapa manfaat, di antaranya:

1) pembentukan kemampuan motorik yang lebih sempurna pada kedua tangan

2) peningkatan kemampuan intelektual

3) peningkatan kemampuan daya kreatif

4) merangsang kinerja seimbang antara bagian otak kiri dan kanan

5) peningkatan daya imajinasi

6) meningkatkan kemampuan memusatkan perhatian (dapat dikatakan meningkatkan konsentrasi)

7) meningkatan kemampuan daya ingat (memori)

8) melatih kesabaran

9) memberikan pengalaman emosional dan estetis 
10) membuat seseorang bisa lebih menghargai kenikmatan, kepuasan, dan kebanggaan akan hasil kerjanya.

Berdasarkan poin-poin manfaat origami di atas, maka dapat diuraikan atau dijabarkan lagi bahwa origami juga bermanfaat pada pengenalan istilah geometris bagi anak-anak yang baru mempelajari geometri, contohnya: segi empat, persegi panjang, lingkaran, garis, titik, perpotongan 2 buah garis, titik pusat, segitiga, dan bangun ruang sejenisnya.

Bermain origami juga dapat meningkatkan keterampilan motorik halus anak, menekan kertas dengan ujung-ujung jari adalah latihan efektif untuk melatih motorik halus anak. Selain itu, anak-anak juga dapat memahami pentingnya akurasi. Saat membuat model origami terkadang kita harus membagi 2, 3 atau lebih kertas, hal ini membuat anak belajar mengenai ukuran dan bentuk yang diinginkan serta keakuratannya. Ketika bermain origami anak juga harus membiasakan diri untuk mengikuti instruksi yang runut dan sistematis. Hal ini menjadi dampak positif bagi kepatuhan seorang anak terhadap suatu aturan, selain itu anak juga dapat berpikir logis dan analitis.

Dengan melatih origami secara konsisten juga merupakan latihan berkonsentrasi, dan hal ini dapat dijadikan sebagai ajang latihan untuk memperpanjang rentang konsentrasi seorang anak, dengan syarat origami dilakukan secara kontinyu dan model yang diberikan bertahap dari yang paling mudah yang dapat dikerjakan oleh anak lalu terus ditingkatkan sesuai kemampuannya.

Selain hal di atas terdapat pula manfaat berupa peningkatan persepsi visual dan spasial yang lebih kuat. Anak dapat menambah pengetahuan yang lebih banyak tentang hewan dan lingkungan mereka, karena bentuk origami yang dibuat dapat dililih oleh kita dengan bentukbentuk dan dapat dijadikan sebagai media pengenalan hewan dan lingkungan anak.

Kegiatan melipat kertas tidaklah mudah dilakukan oleh anak-anak karena kegiatan melipat membutuhkan beberapa aspek perkembangan. Secara khusus tujuan melipat adalah untuk melatih daya ingat, pengamatan, keterampilan tangan, mengembangkan daya fantasi, kreasi, ketelitian, kerapihan, dan perasaan keindahan agar anak usia sekolah termotivasi dan memiliki keterampilan serta kecakapan dalam kehidupan sehari-hari. Setiap individu sebenarnya memiliki potensi untuk kreatif, dengan berbagai macam bentuknya. Namun, untuk lebih mengoptimalkan dan mengembangkan kreativitas lebih lanjut, maka diperlukan peran lingkungan untuk merangsang dan lebih mengembangkan kreativitas yang sudah ada.

Pengabdian dilaksanakan berupa pelatihan membuat origami kepada anak-anak PAUD. Melalui kegiatan ini, nantinya dapat melatih koordinasi mata dan otot-otot tangan serta konsentrasi pada anak usia dini; melatih motorik halus pada anak sekaligus sarana bermain yang aman, murah, menyenangkan, dan kaya manfaat; lewat origami anak belajar membuat mainannya sendiri sehingga menciptakan kepuasan dibandingkan dengan mainan yang sudah jadi dan beli di toko mainan; membentuk sesuatu dari origami perlu melewati tahapan dan proses tahapan mengajarkan anak untutekun, sabar, serta disiplin untuk mendapatkan bentuk yang diinginkan; anak melalui kegiatan origami diajarkan untuk menciptakan sesuatu, berkarya, dan membentuk model sehingga membantu anak memperluas imajinasi mereka dengan bentukan origami yang dihasilkan, karena berhasil menciptakan sesuatu dari tangan mungil mereka.

Hasil dari kegiatan pengabdian ini anak-anak mengetahui seni melipat kertas/origami serta dapat mempraktekkan bentuk-bentuk sederhana dari materi yang telah disampaikan dan dicontohkan oleh pemateri mengenai origami tersebut. Melihat antusiasme mereka dalam mengikuti kegiatan ini berharap hal ini merupakan indikasi positif bahwa anak-anak PAUD mulai tertarik dengan hal-hal baru dan nantinya dapat mengembangkan pola-pola lain secara otodidak atau bertanya kepada teman lain yang lebih tahu.

Berhasil tidaknya kegiatan pengabdian ini dilakukan, dapat dilihat dari antusias peserta. Antusiasme dari peserta dapat dilihat dari evaluasi kegiatan terhadap peserta. Evaluasi dilakukan dengan mengamati kinerja para peserta. Pada saat berlangsungnya kegiatan, semua peserta mampu mengulangi atau mengikuti materi yang disampaikan. 


\section{KESIMPULAN}

Kegiatan pengabdian ini berhasil memberikan potensi baru dalam meningkatkan kreativitas anak usia dini. Origami bagi anak usia dini merupakan salah satu kegiatan yang sangat menarik dan disukai. Kegiatan origami ini dapat digunakan sebagai salah satu pilihan untuk mengajarkan sesuatu kepada anak karena melalui melipat banyak manfaat yang akan didapatkan oleh anak. Penilaian untuk kegiatan melipat pada anak tidak berdasarkan hasil lipatan tapi lebih kepada proses anak pada saat anak melipat kertas. Dengan origami ini, anak memiliki permainan alternatif yang dapat menjauhkannya dari gawai. Disamping itu, anak-anak telah dilatih untuk berkonsentrasi, kreatif, dan berlatih menyelesaikan masalah yang dihadapi.

Kegiatan ini sangat baik diterapkan, mengingat saat ini sangat sedikit kegiatan sederhana seperti ini dilakukan karena besarnya pengaruh dari beberapa permainan dari gawai. Selain itu, kegiatan-kegiatan lain yang ada di masyarakat juga belum banyak yang menyasar anak kecil. Kalaupun ada sebagian besar hanya fokus pada tumbuh kembang dan kesehatan fisik namun masih banyak yang kurang memperhatikan perkembangan motorik, dimana nantinya akan dapat meningkatkan kreativitas anak. Padahal untuk bertahan dalam persaingan global kedepannya, seorang anak harus kuat secara fisik maupun motorik mengingat perubahanperubahan sistem, pola kerja, ilmu pengetahuan dan lain sebagainya, sangat membutuhkan kemampuan berinovasi dan menyesuaikan diri yang cepat. Berharap kegiatan-kegiatan sederhana seperti ini perlu digalakkan dikalangan usia anak sekolah menengah ke bawah.

\section{UCAPAN TERIMA KASIH}

Tim kegiatan mengucapakn terima kasih kepada Rektor Universitas Andalas, dan Lembaga Penelitian dan Pengabdian kepada Masyarakat (LPPM) Universitas Andalas, yang telah memberikan dukungan untuk kegiatan ini. Ucapan terima kasih juga untuk Wali Nagari Sungai Buluh, serta Pimpinan PAUD Jannatul Na'iem Sungai Buluh, Kabupaten Padang Pariaman.

\section{DAFTAR PUSTAKA}

Agustina, S, E. Danil, Yoserwan, I. Kurniawan, E. Elda. 2016. 'Pembekalan program anti korupsi kepada penerima dana gempa di Kenagarian Pakandangan, Kabupaten Padang Pariman', Jurnal Warta Pengabdian Andalas, 23(3), hal.12.

Alwi, H. (2007) Kamus Besar Bahasa Indonesia. Edisi Ketiga. Jakarta: Balai Pustaka.

Aqib, Z. (2013) Model-Model, Media, dan Strategi Pembelajaran Kontekstual. (Inovatif). Bandung: Yrama Widya.

Arsyad, A. (2006) Media Pembelajaran. Jakarta: PT. Rajagrafindo Persada.

Djiwandono, Sri Esti Wuryani. 2006. Psikologi Pendidikan. PT Gramedia Hurlock, E.B. 2002. Psikologi Perkembangan: Suatu Pendekatan Sepanjang. Rentang Kehidupan (Alih Bahasa Istiwidayanti, dkk). Jakarta: Erlangga.

Sadiman, Arief, S. 2007. Media pendidikan. Bandung: Alfabeta.

Suprihatiningrum, Jamil. 2013. Strategi Pembelajaran. Ar-Ruzz Media.

Yanti, D, Santosa, E.G. Ekaputra, Mislaini, O.C. Chatib, F. Irsyad. 2016. 'Pemanfaatan sludge hasil ikutan biogas dari kotoran sapi untuk pembuatan kompos pada Kelompak Tani Indah Sakato 
Kenagarian Kasang Kecamatan Batang Anai Kabupaten Padang Pariaman', Jurnal Warta Pengabdian Andalas, 23(1), hal.8. 